\begin{tabular}{|c|c|}
\hline & Volume \& Issues Obtainable at The Women University Multan \\
Annals of Social Sciences and Perspective \\
ISSN: 2707-7063, Volume 2, No.2 December 2021
\end{tabular}

\title{
Affordability and Work-Family Balance as Key Predictors of Favorable Attitude Towards Online Business in Women E-Entrepreneurs of Pakistan
}

\author{
Amal Sajjad1, Jawad Tariq ${ }^{2}$, Ahmed Usman ${ }^{3}$, Inam ul Haq ${ }^{4}$ \\ ${ }^{1}$ Doctoral Scholar, Department of Sociology, Institute of Social and Cultural Studies, University of the Punjab, Lahore, \\ Pakistan. \\ ${ }^{2}$ Assistant Professor, Department of Sociology \& Coordinator, Population Research Center, Forman Christian College (A \\ Chartered University), Lahore, Pakistan. \\ ${ }^{3}$ Associate Professor, Department of Sociology \& Director, Centre for Research on SDGs, Institute of Socialand Cultural \\ Studies, University of the Punjab, Lahore, Pakistan. \\ ${ }^{4}$ Assistant Professor, Govt. Islamia College Kasur, Pakistan.
}

\begin{tabular}{|c|c|}
\hline \multicolumn{2}{|c|}{ ARTICLE DETAILS } \\
\hline History: & \\
\hline Received: & May 18, 2021 \\
\hline Review: & June 25,2021 \\
\hline Accepted: & October 28, 2021 \\
\hline Available Online: & October 28,2021 \\
\hline
\end{tabular}

Keywords:

E-Entrepreneurship, Women

Empowerment, Work-Family

Balance, Pakistan.

DOI:

10.52700/assap.v2i2.59

\section{ABSTRACT}

The study assessed the role of factors, affordability and work family balance, in shaping the favorable attitude of women Facebook e-entrepreneurs towards online businesses in Pakistan after controlling for socio-demographic, household, and business characteristics. Data from a nonrandom sample of 112 women eentrepreneurs operating their online businesses through Facebook was analyzed. The independent variables were affordability and work life balance and the dependent variable was the favorable attitude towards online businesses. Data were analyzed using SPSS. Factor analysis and reliability analysis were done to assess the validity and reliability of the scales used in the study. Hierarchical multiple regression was carried out to assess the effect of independent variables on the dependent variable. The study found that affordability/low startup cost of business and work life balance were statistically significant determinants of favorable attitude towards online businesses. All control variables added in the model were statistically insignificant. The study recommends that interventions such as providing e-entrepreneurship training to vulnerable segments of the women population can increase their empowerment. The study also suggests that action based studies should be carried out to assess the effect of e-entrepreneurship on women empowerment.

(c) 2021 The Authors, Published by WUM. This is an Open Access Article under the Creative Common Attribution Non Commercial 4.0

Corresponding author's email address: jawadtariq@fccollege.edu.pk

\section{Introduction}

Gender disparity is persistent in developing and underdeveloped countries such as Pakistan even though many scholars have regarded gender equality as an important factor for the socioeconomic and political development of any country (Mohanty \& Mishra, 2020). The research literature reveals that economic development is dependent on higher labor force 
participation nevertheless the statistics suggest that female labor force participation in Pakistan is $25 \%$ which is very less than other Asian countries such as China, Korea, and Indonesia (Asian Development Bank [ADB], 2016a). This data presents a grave picture of women empowerment in Pakistan keeping in view that $25 \%$ of labor force participation is very low as women comprise 104 million (48.5\%) of the total population of 216 million (World Bank, 2020). The World Economic Forum (WEF) in 2020 in its Gender Gap Report reported Pakistan on the third last position out of a total of 153 countries concerning gender equality and the fourth last country concerning the economic opportunity and participation (WEF, 2020). According to the Pakistan Bureau's of Statistics Labor Force Survey (201718), the civilian labor force participation in the population, aged 10 years and above showed a sharp contrast between men and women as only $22.5 \%$ of the women were in the workforce as compared to $77.5 \%$ of men. Concerning augmented labor force, $34.4 \%$ of men were in the labor force as compared to $17.2 \%$ women and $32.4 \%$ of women were out of the labor force as compared to $16.1 \%$ of men. The breakdown with respect to major industry sectors showed that men dominated significantly in all divisions except the businesses performed through homes which comprised just $1.34 \%$ of the total percentage, of which the share of women was $0.79 \%$. Likewise, only $4.3 \%$ of the women were self-employed as compared to $30.5 \%$ of men. Of the $17.2 \%$ employed population informal and $44.3 \%$ in informal sectors, men comprised $15.2 \%$ and $39.1 \%$ as compared to women's share of $2.03 \%$ and $5.17 \%$, respectively. A sharp contrast with respect to wages could also be seen between both genders, as the average monthly salary of men was Rs. 19943/- as compared to Rs. 11884/- of women, with $80.3 \%$ men earning an average monthly income of Rs. 10,000/- and over as compared to $31.8 \%$ of women in the same bracket.

There are many barriers to women's participation in the labor force which include but are not limited to lack of institutional support, unfavorable societal attitudes towards women's employment, and lack of finances (Qureshi et al., 2013). Due to the patriarchal bend of Pakistani society and the socio-cultural traditions associated with it, women in Pakistan are confined to homes even in urban areas, and the prime responsibility allocated to them in the division of labor is familial care and household responsibilities (Jamali, 2009). A brief by ADB in 2016 showed that the majority of the women in Pakistan were either working at farms or in homes and this devoid them of the opportunity to work in the domains outside the home where many opportunities are present (ADB, 2016b). Likewise, women were less likely to take employment outside the home due to socio-cultural norms and security concerns, as $40 \%$ of women reported that they were not allowed to work outside by male members of the family whereas $15 \%$ reported that they did not want to work outside the domain of the house. Furthermore, of women who were involved in labor, 30\% worked from home, and one third of those who were currently not working but willing to work showed their intention to work only if they get an opportunity of working from home (ADB, 2016b). Various studies point out that those women who are working outside as employees are more likely to experience these conflicts as compared to those who are self-employed or working from home (Rembulan et al., 2016).

Research literature suggests that many women are now becoming increasingly interested in online businesses due to developments in Information and Communication Technologies (ICTs). Women who are willing to work but cannot take up outside employment due to familial responsibilities and other socio-cultural constraints can utilize these technologies to gain self-employment or even work as an employee due to the characteristics of these ICTs such as low temporal and spatial restrictions (Zafar et al., 2019; Hossain et al., 2018), thereby helping them to reduce work-family conflict and balancing their personal and professional 
lives (Mukolwe \& Korir, 2016; Melissa et al., 2013). In this sense, online businesses have the potential to not only increase women's participation in the labor force but can also help them to become empowered by gaining financial autonomy (Hossain et al., 2018). Likewise, studies highlight that online businesses in comparison with offline ones are more resource efficient as such businesses often do not require hefty capital, such as infrastructure cost, for their initiation [Zafar et al., 2019; Hossain et al., 2018; Melissa et al., 2013). The present study in this context will attempt to understand the motivations of women who were using ICTs to work from home. The study specifically hypothesizes that women operating online businesses were motivated to pursue this type of business due to the low startup cost and their desire to achieve work-family balance. The study will be limited to only those women who were primarily using Facebook to run small scale businesses.

\section{Methods}

A structured cross-sectional online survey using Google Forms was posted in three Facebook women groups that were created and moderated by women belonging to Pakistan. The sample size was calculated using $\mathrm{G}^{*}$ Power $(v .3 .1)$ by using the following indications; Effect size $\mathrm{f}^{2}=0.15, \alpha=0.05,1-\beta=0.80$, number of predictors $=9$. The results reported that a sample size of 114 women e-entrepreneurs was sufficient to carry out this study. The description of the survey requested women who were using Facebook to carry out their business ventures to fill out the survey and also share the link with other women eentrepreneurs who were running their businesses using Facebook. The total forms received by the end of two months were 130 in number of which 18 were not included in the study due to missing responses. The data of the remaining forms $(\mathrm{N}=112)$ was exported to Software Package for Social Sciences (SPSS, v. 25) for analysis. The sample of 112 women eentrepreneurs was almost equal to the sample size estimated through G*Power. The structured survey questionnaire used for this study included participants' socio-demographic, household, and business characteristics such as age, education, marital status, monthly income, type of business, duration of business, and the number of e-sources used. The major predictor variables were adopted from Hossain et al. (2018) study of women e-entrepreneurs in Bangladesh and the two sub-scales related to women perceptions of work life and flexibility ( 5 items) offered by online businesses and the affordability/set-up cost (3 items) of such businesses were used to measure independent variables. The dependent variable, favorable attitude towards e-entrepreneurship was measured using the sub-scale of favorable attitude towards adoption of e-entrepreneurship ( 5 items) used by Hossain et al. (2018). One of the items measuring favorable attitude [I was motivated to identify an entrepreneurial opportunity through social media] was dropped as the factor loading of the item assessed after data collection was 0.23 . The response categories for all the scales were standardized with responses ranging from strongly disagree, a score of -2 , to strongly agree, which was given a score of 2 . The ethics dealing with confidentiality and anonymity of the participants were observed strictly and the consent form ensured the participants that ethics of confidentiality and anonymity would be observed throughout and their participation in the study would be voluntary and they had a choice to withdraw from the study anytime they want. They were further ensured in the consent form that the data collected from them would be presented in aggregate form so that no response could be traced to any particular person/business. The scales used in the study were tested for reliability and validity using statistical procedures such as factor analysis and reliability analysis (see Table 1). Descriptive statistics such as mean and standard deviation were generated for continuous variables and frequencies and percentages were used to present categorical variables (see Table 2). Hierarchical multiple regression analysis was used to test the model of this study. In the first 
step, control variables were entered into the model, followed by affordability and work life balance in the next step. The assumptions related to linearity were fulfilled as assessed by visual inspection of partial regression plots and studentized residuals plot against the predicted values. Durbin-Watson value was 2.23 which showed that independence of residuals was present and visual inspection of the Q-Q plot showed that normality was present. Homoscedasticity was present as assessed through the plot of studentized residuals versus unstandardized predicted values. Multicollinearity was not present as tolerance values for all predictors were greater than 0.2 and close to 1 and VIF values for all predictor variables were less than 5 .

\section{Results}

Table 1 shows the validity and reliability measures for affordability, work life balance, and attitude towards e-entrepreneurship. The KMO values for all three constructs were greater than 0.6 which showed that sampling adequacy was there and the $p$-values of Bartlett's Test of Sphericity were significant which showed that items relevant to their constructs were not orthogonal. The factor loadings of all items about their relevant construct were greater than 0.5 which showed that construct validity was present and the Average Variance Extract (AVE) for all constructs was greater than 0.50 which showed that at least $50 \%$ of the variation in the construct can be explained by the relevant items. The values of Cronbach's alpha and Composite Reliability were greater than 0.7 for all constructs which showed that internal consistency and construct reliability were present.

Table 1: Assessing Validity and Reliability of Constructs $(\mathrm{N}=112)$

\begin{tabular}{|c|c|c|c|c|c|c|c|}
\hline Variables & Items & KMO & $\begin{array}{l}\text { Bartlett's } \\
\text { ( } p \text {-value) }\end{array}$ & Loadings & $\mathrm{AVE}^{*}$ & $\mathrm{CR}^{* *}$ & $\alpha^{* * *}$ \\
\hline \multirow[t]{4}{*}{ Affordability } & & 0.680 & $<0.001$ & & 0.547 & 0.783 & 0.822 \\
\hline & Item 1 & & & 0.715 & & & \\
\hline & Item 2 & & & 0.819 & & & \\
\hline & Item 3 & & & 0.678 & & & \\
\hline \multirow[t]{6}{*}{ Work Life Balance } & & 0.771 & $<0.001$ & & 0.651 & 0.903 & 0.828 \\
\hline & Item 1 & & & 0.812 & & & \\
\hline & Item 2 & & & 0.841 & & & \\
\hline & Item 3 & & & 0.809 & & & \\
\hline & Item 4 & & & 0.796 & & & \\
\hline & Item 5 & & & 0.775 & & & \\
\hline \multirow{5}{*}{$\begin{array}{l}\text { Attitude towards E- } \\
\text { entrepreneurship }\end{array}$} & & 0.769 & $<0.001$ & & 0.501 & 0.793 & 0.854 \\
\hline & Item 1 & & & 0.702 & & & \\
\hline & Item 2 & & & 0.717 & & & \\
\hline & Item 3 & & & 0.752 & & & \\
\hline & Item 4 & & & 0.623 & & & \\
\hline
\end{tabular}

*, Average Variance Extract; **, Composite Reliability; ***, Cronbach’s Alpha

Table 2 summarizes the descriptive statistics of variables used in this study. Results show that $52.7 \%$ of the women e-entrepreneurs were in the age bracket of 21 to 30 years and $47.3 \%$ were greater than 30 years of age. $72.3 \%$ of the women e-entrepreneurs had formal schooling of eight years and higher. With respect to marital status, $56.3 \%$ were currently married, $29.5 \%$ were unmarried, and $14.3 \%$ were divorced. $36.6 \%$ of the women reported a monthly income of Rs. 51,000/- and higher. The majority of the women, that is $71.4 \%$, were involved 
in the business of goods whereas $28.6 \%$ were providing services. $61.6 \%$ of the women eentrepreneurs had an online business experience of one year and higher. Furthermore, it was found that $90.2 \%$ of the women e-entrepreneurs were using two or more online platforms to run their businesses. The mean, standard deviation, and range of responses for affordability, work life balance, and attitude towards E-entrepreneurship are summarized in Table 2.

Table 2: Descriptive statistics of variables $(\mathrm{N}=112)$

\begin{tabular}{|c|c|c|c|c|c|}
\hline Variables & $\mathrm{F}$ & $\%$ & Mean & SD & Range \\
\hline \multicolumn{6}{|l|}{ Age } \\
\hline $21-25$ years & 35 & 31.3 & & & \\
\hline $26-30$ years & 24 & 21.4 & & & \\
\hline$>30$ years & 53 & 47.3 & & & \\
\hline \multicolumn{6}{|l|}{ Education } \\
\hline No formal schooling & 12 & 10.7 & & & \\
\hline Less than eight years & 19 & 17.0 & & & \\
\hline Eight years \& higher & 81 & 72.3 & & & \\
\hline \multicolumn{6}{|l|}{ Marital Status } \\
\hline Single & 33 & 29.5 & & & \\
\hline Married & 63 & 56.3 & & & \\
\hline Divorced & 16 & 14.3 & & & \\
\hline \multicolumn{6}{|l|}{ Monthly Income } \\
\hline$<$ Rs. 10,000 & 15 & 13.4 & & & \\
\hline Rs. $10,000-30,000$ & 31 & 27.7 & & & \\
\hline Rs. $31,000-50,000$ & 25 & 22.3 & & & \\
\hline Rs. $51,000-70,000$ & 08 & 7.1 & & & \\
\hline Rs. $71,000-100,000$ & 13 & 11.6 & & & \\
\hline$>$ Rs. 100,000 & 20 & 17.9 & & & \\
\hline \multicolumn{6}{|l|}{ Type of Business } \\
\hline Goods & 80 & 71.4 & & & \\
\hline Services & 32 & 28.6 & & & \\
\hline \multicolumn{6}{|l|}{ Duration of Business } \\
\hline$<1$ year & 43 & 38.4 & & & \\
\hline $1-2$ years & 35 & 31.3 & & & \\
\hline$>2$ years & 34 & 30.3 & & & \\
\hline Total E-sources used & & & 2.55 & 0.78 & $1-5$ \\
\hline 1 & 11 & 9.8 & & & \\
\hline 2 & 35 & 31.2 & & & \\
\hline$>2$ & 66 & 59.0 & & & \\
\hline Affordability & & & 3.07 & 2.89 & $-6-6$ \\
\hline Work Life Balance & & & 4.71 & 4.38 & $-10-10$ \\
\hline Attitude towards E-entrepreneurship & & & 4.38 & 3.69 & $-7-8$ \\
\hline
\end{tabular}

The results of hierarchical multiple regression analyses showed that the model predicting favorable attitude towards adoption of e-entrepreneurship through control variables was statistically insignificant and only accounted for $2 \%$ of the variation, $R^{2}=0.02, F(7,104)=$ $0.322, p=0.942$. All control variables were statistically insignificant $(p>0.05)$. The values of unstandardized beta, standard error of beta, and significance are summarized in Table 3 under Model 1. The addition of affordability and work life balance in the next step accounted for $50.5 \%$ of variation in the model, $R^{2}$ change $=0.505, F(2,102)=54.40, p<0.001$. The full 
model (Model 2) was statistically significant and explained $52.6 \%$ of variation in attitude towards e-entrepreneurship, $R^{2}=0.526, F(9,102)=12.60, p<0.001$. All of the control variables were statistically insignificant $(p>0.05)$ in Model 2 as well. The values of unstandardized beta, standard error of beta, and significance are summarized in Table 3 under Model 2. The value of unstandardized beta for affordability shows that one unit change in affordability significantly increased favorable attitude towards E-entrepreneurship by 0.43 units, $B=0.43, p<0.001$. Likewise, one unit increase in work life balance significantly increased favorable attitude towards E-entrepreneurship by 0.39 units, $B=0.39, p<0.001$.

Table 3: Hierarchical Multiple Regression predicting Attitude towards Eentrepreneurship $(\mathrm{N}=112)$

\begin{tabular}{|c|c|c|c|c|c|c|}
\hline \multirow{3}{*}{ Variables } & \multicolumn{6}{|c|}{ Attitude towards E-entrepreneurship } \\
\hline & \multicolumn{2}{|c|}{ Model 1} & \multicolumn{4}{|c|}{ Model 2} \\
\hline & $\mathrm{B}$ & $\mathrm{B}$ & $p$-value & $\mathrm{B}$ & $\mathrm{B}$ & $p$-value \\
\hline Age & 0.09 & 0.47 & 0.85 & 0.01 & 0.33 & 0.97 \\
\hline Marital Status & -0.20 & 0.87 & 0.82 & 0.32 & 0.62 & 0.60 \\
\hline Education & 1.30 & 1.19 & 0.28 & 1.03 & 0.84 & 0.22 \\
\hline Monthly Income & -0.14 & 0.24 & 0.55 & -0.03 & 0.17 & 0.86 \\
\hline Business Type & -0.20 & 0.85 & 0.82 & 0.55 & 0.61 & 0.36 \\
\hline Business Duration & -0.12 & 0.26 & 0.64 & -0.13 & 0.18 & 0.49 \\
\hline Total E-sources & -0.16 & 0.47 & 0.73 & 0.12 & 0.33 & 0.72 \\
\hline Affordability & --- & --- & --- & 0.43 & 0.07 & $<0.001$ \\
\hline Work Life Balance & --- & --- & --- & 0.39 & 0.11 & $<0.001$ \\
\hline$R^{2}$ & 0.02 & & & 0.526 & & \\
\hline$F$ & $0.322^{\mathrm{ns}}$ & & & $12.60^{\circ}$ & & \\
\hline$\Delta \boldsymbol{R}^{2}$ & --- & & & 0.505 & & \\
\hline$\Delta F$ & --- & & & 54.40 & & \\
\hline
\end{tabular}

\section{Discussion}

The study attempted to understand the motivations of women e-entrepreneurs to start their online business and how these factors are related to their favorable attitude towards eentrepreneurship. The study found that affordability/low cost of starting an online business and the work life balance that can be maintained through online business were the primary motivations that shaped the favorable attitude of women towards e-entrepreneurship after controlling for other predictor variables. Some of the literature present on women entrepreneurs and e-entrepreneurs supports the findings of this study. Thébaud (2015) and Kirkwood and Tootell (2008) found that work life balance was the primary motivation behind women starting a business due to the benefits offered by the online domain such as flexible hours. Similarly, Rembulan et al. (2016) found that women who were working as entrepreneurs faced lesser temporal and work related conflicts as compared to those women who were working as employees. Like other patriarchal societies, women in Pakistan are likely to perform household chores which mainly include reproductive and childrearing responsibilities. This means that working women are more likely to engage in dual labor as compared to men because the primary responsibility for the household domain also falls upon them. This can lead to an imbalance in family-work domain and can result in many physiological, psychological, and social negative consequences such as burnout, stress, 
absenteeism, and lower self-complacency, wellbeing, and self-esteem (Neneh, 2018). Eentrepreneurship, in this context, helps women to effectively balance their work and family which serves to reduce workplace burnout and familial stress in addition to increasing economic resources. A lot of studies have also pointed out that women entrepreneurs are more focused on pursuing social than economic goals that not just empower women but also result in the empowerment of the regional community (Bedarkar, 2020). Various studies have shown that a difference in motivation exists between men and women concerning entrepreneurship as men are more likely to choose employment that fosters promotion, attractive payment, and security whereas women are likely to choose entrepreneurial careers that emphasizes flexible hours and freedom of initiative (Zou, 2015). Results from other studies that have emphasized the features of e-entrepreneurship such as affordability and low cost as a motivating factor for women e-entrepreneurs were also consistent with the results of this study (Kartiwi \& Gunawan, 2013). Kartiwi and Gunawan (2013) found that eentrepreneurship provided women with the opportunity to enter the marketplace with low capital and compete with many offline established businesses.

The findings of this study generate strong research and policy implications. One of the barriers to women's participation in the economic domain discussed throughout this study was the lack of capital and the high startup cost of offline businesses. E-entrepreneurship has the potential to become a valuable resource for those women who lack economic capital to start a business. Nevertheless, these findings mustn't be generalized to all segments of the women population in Pakistan as many women are belonging to poor social classes who lack awareness about e-entrepreneurship and even lack the basic technical knowledge to operate contemporary electronic devices. The authors in this regard are currently designing another study to assess changes in the level of women empowerment after providing eentrepreneurship training to a sample of poor women entrepreneurs who are running small scale offline businesses. Though some of the efforts are already being done at public and private levels nevertheless there is a need to increase such training and targeted interventions are required particularly towards those women populations that are more vulnerable. Likewise, e-entrepreneurship provides women operating in a patriarchal culture an excellent opportunity to initiate their home based businesses through online technologies which can create a balance between their family responsibilities and their personal development. Furthermore, such businesses have the potential to increase women's empowerment in the household domain as well as financial autonomy and such businesses can also be later converted to the offline domain once the prerequisites, that are empowerment and financial autonomy, are achieved.

\section{Conclusion}

The study found evidence that e-entrepreneurship is a valuable resource for women who lack business capital as well as face difficulties in working outside the domain of family. The sustainable development goal (SDG) no. 8 considers promoting sustained, inclusive, and sustainable economic growth, full and productive employment and decent employment for all as a precursor for sustainable development and the fulfillment of this goal is inherently linked to the fulfillment of SDG 3, 4, and 5. The policymakers should emphasize utilizing the domain of ICTs to empower women who want to work but cannot get in employment due to various restrictions discussed above. Studies have shown that including women in entrepreneurial activities can reduce poverty and violence, increase economic development, and increase empowerment and wellbeing (Li et al., 2019). It is therefore very important that 
training related to e-entrepreneurship should be provided to women so that they can empower themselves by effectively exploiting the online marketplace.

\section{References}

Asian Development Bank (2016a). Female Labor Force Participation in Asia: Key trends, constraints, and opportunities. Retrieved from https://www.adb.org/sites/default/files/publication/209666/female-labor-forceparticipation-asia.pdf

Asian Development Bank (2016b). Policy brief on female labor force participation in Pakistan. 2016. Retrieved from https://www.adb.org/sites/default/files/publication/209661/female-labor-forceparticipation-pakistan.pdf

Bedarkar, M. M., Mishra, M., \& Khatwani, R. A. (2020). Leveraging Social Media in Facilitating Women Entrepreneurs in India: A Case Study of Pune Ladies (PULA). International Journal of E-Entrepreneurship and Innovation (IJEEI), 10, 76 90. doi: 10.4018/IJEEI.2020070105

Hossain, A., Siddique, M. Z. R., \& Al Jamil, M. A. (2018). Factors affecting women involvement as entrepreneur in SMEs sector, economic development and its impact on poverty reduction in Bangladesh. Business, Management and Economics Research, 4(5), $51-65$.

Jamali, D. (2009). Constraints and opportunities facing women entrepreneurs in developing countries: A relational perspective. Gender in management: an international journal, 24, 232 - 251. doi: 10.1108/17542410910961532

Kartiwi, M., \& Gunawan, T. S. (2013, March). Assessment of e-commerce adoption benefits by Indonesian women entrepreneurs. In 2013 5th international conference on information and communication technology for the Muslim world (ICT4M) (pp. 1-4). IEEE. doi: 10.1109/ICT4M.2013.6518902

Kirkwood, J., \& Tootell, B. (2008). Is entrepreneurship the answer to achieving work-family balance?. Journal of management \& organization, 14, 285 - 302. doi: 10.5172/jmo.837.14.3.285

Li, C., Ahmed, N., \& Qalati, S. A. (2019). Impact of Gender-Specific Causes on Women Entrepreneurship: An Opportunity Structure for Entrepreneurial Women in Rural Areas. Journal of Entrepreneurship \& Organization Managemen, 8(1), 1-9.

Melissa, E., Hamidati, A., \& Saraswati, M. S. (2013). Social media empowerment: How social media helps to boost women entrepreneurship in Indonesian urban areas. The IAFOR Journal of Media, Communication and Film, 1(1), 77 - 90.

Mohanty, E., \& Mishra, A. J. (2020). Understanding the gendered nature of developing country MSMEs' access, adoption and use of information and communication technologies for development (ICT4D). International Journal of Gender and Entrepreneurship, 12, 273 - 295. doi: 10.1108/IJGE-07-2019-0117

Mukolwe, E., \& Korir, J. (2016). Social media and entrepreneurship: Tools, benefits, and challenges. A Case study of women online entrepreneurs on Kilimani Mums marketplace on Facebook. International Journal of Humanities and Social Science, 6(8), 248 - 256.

Neneh, N. B. (2018). Family-work conflict and performance of women-owned enterprises: The role of social capital in developing countries--implications for South Africa and beyond. Journal of International Women's Studies, 19(6), 326-343.

Pakistan Bureau of Statistics (2021). Labor Force Survey (2017-2018). Retrieved from https://www.pbs.gov.pk/content/labour-force-statistics 
Qureshi, S., Abbas, S., Safdar, R., \& Zakar, R. (2013). Gender Responsive Budgeting in Pakistan: Scope and Challenges. Journal of the Research Society of Pakistan, 50(1), 1-26. Retrieved from http://pu.edu.pk/images/journal/history/PDFFILES/Article\%2001\%20Shazia.pdf

Rembulan, C. L., Ratna Indudewi, F. Y., \& Rahmawati, K. D. (2016). Work-family conflict of women entrepreneurs and women employees. AnimaIndonesian Psychological Journal, 31 (3), 111 - 123.

Thébaud, S. (2015). Business as plan B: Institutional foundations of gender inequality in entrepreneurship across 24 industrialized countries. Administrative science quarterly, 60, 671 - 711. doi: 10.1177/0001839215591627

World Bank (2020). Pakistan. Retrieved from https://data.worldbank.org/indicator/SP.POP.TOTL.FE.ZS ?locations=PK

World Economic Forum (2020). Global Gender Gap Report (2020). Retrieved from http://www3.weforum.org/docs/WEF_GGGR_2020.pdf

Zafar, M. Z., Toor, A., \& Hussain, T. (2019). Social Media As Conduit For Women Entrepreneurs in Pakistan. Pakistan Business Review, 20(4), 886 - 889.

Zou, M. (2015). Gender, work orientations and job satisfaction. Work, employment and society, 29, 3 - 22. doi: 10.1177/0950017014559267. 